\title{
A Simple Spectrophotometric Determination of Pantoprazole in Pharmaceutical Formulations
}

\author{
M. PURUSHOTHAM REDDY ${ }^{* 1}$, G. RAMACHANDRA REDDY ${ }^{2}$ and N. RAMI REDDY ${ }^{3}$ \\ ${ }^{1}$ Government Degree College, Bhainsa, AP, India \\ ${ }^{2}$ Department of Humanities, Ravindra College of Engineering, Kurnool, A.P, India \\ ${ }^{3}$ Department of Chemistry, S.B.S.Y.M.Degree College, Kurnool, A.P, India \\ mpreddy60@gmail.com
}

Received 15 August 2013 / Accepted 4 October 2013

\begin{abstract}
Bromocresol green was used to determine pantoprazole either in pure form or in pharmaceutical formulations. A simple and sensitive spectrophotometric method has been described for the assay of pantoprazole either in pure form or in pharmaceutical formulations. The developed methods involve formation of colored chloroform extractable ion-pair complexes of the drug with bromocresol green in acidic medium. The extracted complexes showed absorbance maxima at $420 \mathrm{~nm}$. The proposed method has been successfully applied for the assay of drug in pharmaceutical formulations. No interference was observed from common pharmaceutical adjuvant. Results of analysis were validated statistically and through recovery studies.
\end{abstract}

Keywords: Spectrophotometry, Pantoprazole, Bromocresol green, Ion association complex, Formulations

\section{Introduction}

Pantoprazole is 5- (difluoromethoxy) - [[(3,4- dimethoxy-2-pyridiynyl) methyl] sulphinyl] $1 H$-benzimidazole and it is a proton pump inhibitor drug used for short-term treatment of erosion and ulceration of the esophagus caused by gastroesophageal reflux disease. The literature survey reveals that several methods are available for the determination of pantoprazole in dosage forms which includes voltammetry ${ }^{1}$, RP-HPLC method $^{2-7}$, highperformance liquid chromatography and high-performance thin-layer chromatography method $^{8}$, high performance liquid chromatography ${ }^{9-11}$ and capillary electrophoresis ${ }^{12.13}$. spectrophotometric determination ${ }^{14-20}$. Few methods were reported in literature for the estimation of pantoprazole and other combination drugs which includes spectophotometric methods $^{21-23}$, HPLC method ${ }^{24}$ and RP-HPLC method ${ }^{25}$.

However, no reports have appeared dealing with the extractive spectrophotometric method for the determination of pantoprazole in pharmaceutical formulations so far. Therefore, this paper proposes simple and sensitive extractive spectrophotometric method 
for the assay of pantoprazole. The method was based on ion-pair complexes of drug with dyestuffs such as bromocresol green and subsequent extraction into chloroform under reaction conditions used.

\section{Experimental}

All the absorption spectra were recorded on UV-Visible double beam spectrophotometer (Spectronic 1000 plus spectrophotometer) with $1 \mathrm{~cm}$ quartz cell. The drugs and chemicals were weighed on Shimadzu electronic balance. Glassware used in each procedure were soaked overnight in a mixture of chromic acid and sulphuric acid rinsed thoroughly with double distilled water and dried in hot air oven.

\section{Reagents}

All chemicals were of analytical reagent grade and double distilled water was used to prepare solutions.

\section{Buffer solution ( $p H$ 3.5)}

Buffer solution was obtained by diluting a mixture of $50 \mathrm{~mL}$ of $0.2 \mathrm{M}$ potassium acid phthalate and $8.4 \mathrm{~mL}$ of $0.2 \mathrm{M} \mathrm{HCl}$ to $200 \mathrm{~mL}$ with distilled water and the $\mathrm{pH}$ is adjusted to 3.5.

\section{Bromocresol green $(0.5 \% \mathrm{~W} / \mathrm{V})$}

Bromocresol green solution was prepared by dissolving $500 \mathrm{mg}$ of bromocresol green (Loba) in $100 \mathrm{~mL}$ of distilled water.

\section{Preparation of standard stock solutions}

Stock solution was prepared by accurately weighed $50 \mathrm{mg}$ pantoprazole and transferred into $50 \mathrm{~mL}$ volumetric flasks containing a few $\mathrm{mL}$ of methanol. The flask was swirled to dissolve solids. Volume was made up to the mark with methanol, which gave $1000 \mu \mathrm{g} / \mathrm{mL}$ of the drug. Aliquot from the stock solutions was appropriately diluted with methanol to obtain working standard solutions of $100 \mu \mathrm{g} / \mathrm{mL}$ of drug.

\section{Calibration curve procedure}

Different aliquots of standard drug solution ranging from $0.5-2.5 \mathrm{~mL}$ were placed separately in a series of $125 \mathrm{~mL}$ separating funnels. To each $1.5 \mathrm{~mL}$ bromocresol green and $2.0 \mathrm{~mL}$ of buffer solution were added. The total volume in each funnel was adjusted to $10 \mathrm{~mL}$ with distilled water. Then $5 \mathrm{~mL}$ of chloroform was added to each separating funnel and the contents were shaken for 5 minutes and allowed to separate. The organic layer was collected through cotton plug and the absorbance was immediately measured at $420 \mathrm{~nm}$ against the reagent blank. Both the colored species were stable for $1 \mathrm{~h}$. The calibration curve was constructed by plotting the absorbance versus final concentration of pantoprazole. The amount of the drug was computed from calibration curve in Figure 1.

\section{Tablet formulations}

For analysis of tablet formulation, twenty tablets of pantoprazole were weighed accurately and finely powdered. An accurately weighed portion of powdered sample, equivalent to $50 \mathrm{mg}$ of pantoprazole was taken in a $50 \mathrm{~mL}$ volumetric flask containing $25 \mathrm{~mL}$ of methanol, sonicated for 20 minutes. The resultant solution was filtered through Whatmann filter paper No. 41 into another $50 \mathrm{~mL}$ volumetric flask. The filter paper was washed several times with methanol. The washings were added to the filtrate and the final volume was made up to the mark with methanol and treated as per the procedure of the calibration curve. Amount of the drug 
present in the sample was computed from respective calibration curve. The results are presented in Table 1.

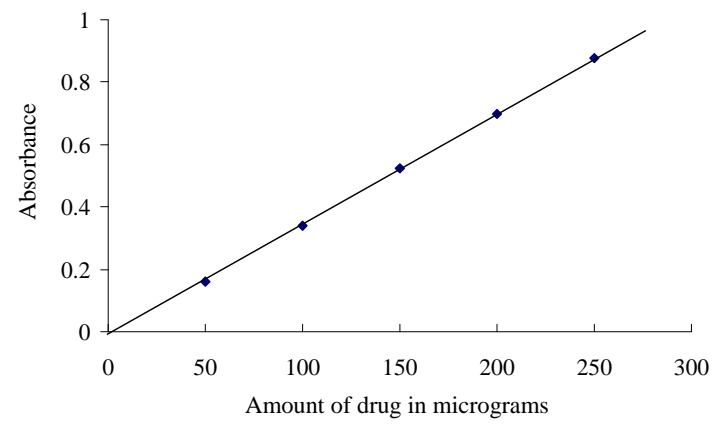

Figure 1. Calibration curve of pantoprazole

Table 1. Assay of pantoprazole in pharmaceutical formulations

\begin{tabular}{cccccc}
\hline Tablets & $\begin{array}{c}\text { Labeled } \\
\text { amount mg }\end{array}$ & $\begin{array}{c}\text { * Amount found } \\
\mathrm{mg} \pm \text { S.D }\end{array}$ & $\begin{array}{c}\% \\
\text { Recovery }\end{array}$ & \%RSD & $\begin{array}{c}{ }^{*} \mathrm{t} \\
\text { value }\end{array}$ \\
\hline Tablet 1 & 40 & $40.01 \pm 0.33$ & 100.22 & 0.0849 & 0.0658 \\
Tablet 2 & 40 & $39.98 \pm 0.25$ & 99.9 & 0.6473 & 0.1728 \\
Tablet 3 & 40 & $40.07 \pm 0.23$ & 100.1 & 0.5957 & 0.6560 \\
\hline
\end{tabular}

\section{Results and Discussion}

Pantoprazole forms ion-pair complexe in acidic buffer with bromocresol green and the complex was quantitatively extracted into chloroform. The ion-pair complex with bromocresol green absorbed maximally at $420 \mathrm{~nm}$, respectively. The colorless reagent blanks under similar conditions showed no absorption. Commercial formulation of pantoprazole was successfully analyzed by the proposed method. The values obtained by the proposed method are presented in Table 1 . The percent relative standard deviation calculated for five measurements of pantoprazole is shown in Table 1. The \% RSD is less than 2, which indicates that the method has good reproducibility. The values of standard deviation are low, indicates high accuracy and reproducibility of the method. The ' $\mathrm{t}$ ' values calculated are compared well with the theoretical value of 2.78 there by indicating that the precision of the method is high summarized in Table 1. Interference studies revealed that the common excipients and other additives usually present in dosage form did not interfere in the proposed method.

The proposed methods are simple, sensitive and reproducible and can be used for routine analysis of pantoprazole in pure form and in formulations. Proposed methods make use of simple reagents, which an ordinary analytical laboratory can afford.

\section{References}

1. $\quad$ Sacide Altınoz and Incilay Süslü, Anal Lett., 2005, 38(9), 1389-1404; DOI:10.1081/AL-200062195

2. Zeinab Abdelaziz El-Sherif, Afaf Osman Mohamed, Mohamed Galal El-Bardicy and Mohamed Fayez El-Tarras, Chem Pharm Bull.. 2006, 54, 6814-6818.

3. Prasanna Kumar Reddy B, Ramanjaneya Reddy Y and Ramachandran D, J Chem., 2009, 6(2), 489-494; DOI:10.1155/2009/502472

4. Liu W F and Chen JHu Gy, Chin J Pharm Anal., 2006, 26, 784-786. 
5. Xie Z, Chen X, Jin F and Zhong D, J Chromatogr Sci., 2005, 43(5), 271-275; DOI:10.1093/chromsci/43.5.271

6. Tanaka M and Yamazaki H, Anal Chem., 1996, 68(9), 1513-1516;

DOI:10.1021/ac951127n

7. Prasanna Reddy B and Kirankumar Reddy N, Int J Chem Tech Res., 2009, 1, 195-198.

8. Patel Bhavesh H, Suhagia Bhanubhai N, Patel Madhabhai M and Patel Jignesh R, $J$ AOAC Int., 2007, 90(1), 142-146.

9. Ramakrishna N V, Vishwottam K N, Wishu S and Koteshwara M, J Chromatogr B Anal Technol Biomed Life Sci., 2005, 822(1-2), 326-329.

10. Saini V and Gupta V B, Int J PharmTech Res., 2009, 1(4), 1094-1096.

11. Tanaka M, Yamazaki H and Hakusui H, Chirality, 1995, 7(8), 612-615; DOI:10.1002/chir.530070810

12. Tivesten A, Folestad S, Schonbacher V and Svensson K, Chromatographia, 1999, 49, S7-S11; DOI:10.1007/BF02468970

13. Daniela E, Rolf P H and Reinhard K, J Chromatogr A, 1997, 759(1-2), 185-192; DOI:10.1016/S0021-9673(96)00769-8

14. Urdigere Rangachar, Anil Kumar and Basavaiah K, Bull Chem Soc Ethiop., 2008, 22(1), 135-141; DOI:10.4314/bcse.v22i1.61350

15. Basavaiah K, Urdigere Rangachar and Anil Kumar, Bulgarian Chemical Communications, 2007, 39(2), 159-164;

16. Rahman N and Kashif M, Pharmazie, 2005, 60(3), 197-200.

17. Nafisur Rahman, Zehra Bano and Syed Najmul Hejaz Azmi, Anal Sci.. 2006, 22(7), 983-988; DOI:10.2116/analsci.22.983

18. Kalaichelvi R, Fatima Rose M, Vadivei K and Jayachandran E, Int J Chem Res., 2010, 1(1), 6-8

19. Okram Zenita Devi and Kanakapura Basavaiah, Int J ChemTech Res., 2010, 2(1), 624-632.

20. Rajnish Kumar Harinder Singh and Pinderjit Singh, J Chem Pharm Res., 2011, 3(2), 113-117.

21. Azza Moustafa A M, J Pharm Biomed Anal., 2000, 22(2), 45-58; DOI:10.1016/S0731-7085(99)00275-7

22. Ravi Kumar P, Banu Prakash P, Murali Krishna M, Santha Yadav M and Asha Deepthi C, J Chem., 2006, 3(3), 142-145; DOI:10.1155/2006/640731

23. Kakde R B, Gedam S N, Chaudhary N K, Barsagade A G, Kale D L and Kasture A V, Int J Pharm Tech Res., 2009, 1(2), 386-389.

24. Deepak Bageshwar, Vineeta Khanvilkar and Vilasrao Kadam. J Pharm Anal., 2011, 1(4), 275-283; DOI:10.1016/j.jpha.2011.09.012

25. Patel B H, Suhagia B N, Patel M M and Patel J R. J AOAC Int., 2007, 90(1), 142-146. 